\title{
FERMENTABILITAS RANSUM SAPI PERAH BERBASIS JERAMI PADI YANG MENGANDUNG KONSENTRAT YANG DIFERMENTASI OLEH Saccharomyces creviseae DAN EM-4
}

\author{
HERNAMAN I., A. R. TARMIDI, DAN T. DHALIKA \\ Fakultas Peternakan Universitas Padjadjaran \\ e-mail : iman_hernaman@yahoo.com
}

\begin{abstract}
ABSTRAK
Musim kemarau menyebabkan banyak peternak sapi perah memanfaatkan jerami padi sebagai pakan sumber serat, namun bahan pakan ini memiliki kualitas dan kecernaan nutrien yang rendah. Pengunaan konsentrat fermentasi diharapkan dapat menutupi kekurangan limbah tersebut dalam ransum. Penelitian menggunakan Rancangan Acak Lengkap dan data yang terkumpul dianalisis dengan Uji Kontras Orthogonal. Ransum percobaan terdiri atas 1) 50\% jerami padi+50\% konsentrat 2) 50\% jerami padi+25\% konsentrat $+25 \%$ konsentrat terfermentasi. 3) $50 \%$ jerami padi $+50 \%$ konsentrat terfermentasi. Konsentrat terfermentasi yang digunakan diperoleh dari hasil fermentasi oleh Saccharomyces cerevisiae dan Effective Microorganisms-4 (EM-4) selama 3 hari. Hasil menunjukkan bahwa penggunaan konsentrat terfermentasi sebanyak 50\% dalam ransum dapat menurunkan $(\mathrm{P}<\mathrm{O}, 05)$ produksi asam lemak terbang dan $\mathrm{N}-\mathrm{NH}_{3}$ dalam cairan rumen dengan rataan konsentrasi yang diperoleh untuk masing-masing sebesar 114 dan 4,27 mM, namun konsentrasi ini masih dalam kisaran yang dibutuhkan oleh mikroba rumen. Kesimpulan, konsentrat termentasi dapat digunakan sampai 50\% dalam ransum sapi perah berbasis jerami padi.
\end{abstract}

Kata Kunci: Microorganisms-4, fermentabilitas, jerami padi, konsentrat, Saccharomyces cerevisiae, sapi perah

\section{THE FERMENTABILITY OF RICE STRAWS BASED DAIRY COWS' RATION CONTAINING CONCENTRATE FERMENTED BY SACCHAROMYCES CREISEAE AND EM-4}

\begin{abstract}
During dry season, many dairy farmers use rice straws as fiber source of diet. However, this low quality feed has also minimal nutrients digestibility so that the use of concentrate can improve the quality of the diet. This reseach used a Completely Randomized Design and the data was analyzed with Orthogonal Contrast Test. The experimental diets consisted of 1) $50 \%$ rice straws $+50 \%$ concentrate, 2) $50 \%$ rice straws $+25 \%$ concentrate $+25 \%$ fermented concentrate, 3 ) $50 \%$ rice straws $+50 \%$ fermented concentrate. Fermented concentrate was produced by fermenting concentrate with the help of Saccharomyces cerevisiae and Effective Microorganisms-4 (EM-4) for 3 days. The results showed that the use of $50 \%$ fermented concentrate decreased $(\mathrm{P}<0.05)$ volatile fatty acids and $\mathrm{NH}_{3}$ productions in vitro with the averaged values of 114 and $4.27 \mathrm{mM}$, respectively. These concentrations are still in the range of microbials need. It can be concluded that fermented concentrate can be used up to $50 \%$ in rice straws based dairy cows' diets.
\end{abstract}

Keywords: Effective microorganisms-4, fermentability, rice straws, concentrate, Saccharomycescerevisiae, dairy cows

\section{PENDAHULUAN}

Kelangkaan hijauan pakan di musim kemarau memaksa peternak sapi perah memanfaatkan jerami padi sebagai pengganti rumput. Padahal jerami padi memiliki kualaitas nutrien dan kecernaan yang rendah, sehingga tidak dapat mencukupi untuk kebutuhan sapi perah dalam memproduksi susu yang maksimal (Wanapat, 1985; Wanapatetal.2013).Untukmelengkapi kebutuhan nutrien pada sapi perah berbasis limbah 
pertanian hendaknya diberi pakan tambahan berupa konsentrat, dan hal ini terbukti dapat meningkatkan produktivitasnya (Wardhani dan Musofie, 1985).

Pada musim yang sama ternyata banyak juga bahan baku konsentrat yang terbatas ketersediaannya, sehingga terpaksa memanfaatkan bahan pakan alternatif berupa produk pangan yang sudah kadaluarsa. Hal ini mengingat jumlahnya yang cukup banyak seperti mie, tepung terigu, dan tepung beras afkir. Namun limbah ini seringkali mengandung zat pengawet, sudah berjamur dan bau tengik yang dikhawatirkan dapat mengurangi palatabilitas dan derajat kesehatan hewan.

Masalah tersebut sebenarnya dapat dikurangi, jika sebelum diberikan pada ternak, terlebih dahulu diolah melalui proses fermentasi. Penelitian telah membuktikan bahwa pengolahan dengan fermentasi memberikan banyak keuntungan diantaranya aroma pakan menjadi lebih baik, mengurangi atau menghilangkan senyawa beracun dan antinutrisi, meningkatkan kualitas dan palatabilitas pakan serta mampu meningkatkan produksi susu (Callaway dan Martin, 1997; Westby et al. 1997; Reddy dan Pierson 1994; Eastridge, 2006; Salcedo et al. 2010).

Saccharomyces cerevisieae dan Effective Microorganism-4 (EM-4) adalah mikroorganisme dan kumpulan mikroorganisme yang banyak digunakan sebagai agen yang bersifat fermentasi (peragian) dan sintetik (Umiyasih dan Anggraeny 2008; Surung, 2008). Banyak penelitian yang menggunakan mikroorganisme tersebut sebagai agen fermentasi ternyata mampu menghasilkan kualitas pakan yang lebih baik serta produknya mampu meningkatkan produktivitas ternak.

Penelitian bertujuan untuk mengkaji fermentabilitas ransum sapi perah berbasis jerami padi yang mengandung konsentrat yang telah difermentasi oleh Saccharomyces cerevisieae dan EM-4 secara In Vitro.

\section{MATERI DAN METODE PENELITIAN}

Saccaromyces cerevisiae dan EM-4 sebanyak $0,125 \% \mathrm{v} / \mathrm{b}$ dan $0,5 \%$ ditambahkan pada konsentrat yang tersusun dari campuran beberapa bahan baku pakan yang terdiri atas mie kering afkir, terigu afkir, tepung beras afkir, kulit kopi, dedak, ongok, kedelai, ampas kecap, molases, urea, mineral, dan premix. Kondisi akhir konsentrat yang telah dicampur inokulum mengandung kadar air sebesar 30\%. Konsentrat yang telah ditambahkan inokulum dimasukan ke dalam kantong plastik dan ditimbang sebanyak $2 \mathrm{~kg}$, lalu difermentasi selama 3 hari.

Sampel konsentrat terfementrasi dicampur dengan jerami padi sesuai dengan perlakuan (Tabel 1) dan ditimbang masing-masing sebanyak 0,5g, kemudian diuji fermentabilitasnya secara in vitro (Tilley dan
Terry 1963) dengan mengunakan cairan rumen sapi perah sebagai inokulum. Setelah 3 jam masa inkubasi diambil cairan rumennya untuk diukur konsentrasi $\mathrm{N}-\mathrm{NH}_{3}$ menggunakan metode mikrodifusi pada cawan Conway (Conway, 1962) dan konsentrasi asam lemak terbang (VFA) mengunakan seperangkat alat destilasi uap Markham (Markham, 1942).

Percobaan dilakukan secara eksperimental dengan Rancangan Acak Lengkap terdiri atas 3 perlakuan dan 6 ulangan. Data yang terkumpul dilakukan analisis Uji Kontras Orthogonal (Steel dan Torrie 1993).

Tabel 1. Susunan dan Kandungan Nutrien Ransum Percobaan

\begin{tabular}{rlccc}
\hline \multirow{2}{*}{ No } & \multicolumn{1}{c}{ Bahan Pakan } & R1 & R2 & R3 \\
\cline { 2 - 4 } & & 50 & 50 & 50 \\
\hline 1 & Jerami Padi & 50 & 25 & - \\
2 & Konsentrat & - & 25 & 50 \\
3 & Konsentrat Terfermentasi & & & \\
Kandungan Nutrien & 16,26 & 16,65 & 17,04 \\
1 Abu (\%) & 8,24 & 8,79 & 9,34 \\
2 & Protein Kasar (\%) & 4,04 & 4,25 & 4,47 \\
3 & Lemak Kasar (\%) & 27,11 & 26,28 & 25,46 \\
4 & Serat Kasar (\%) & 44,37 & 44,04 & 43,71 \\
5 & Bahan Ekstrak Tanpa Nitrogen (\%) & 60,61 & 61,56 & 62,51 \\
6 Total Digestible Nutrient (\%) & & & \\
\hline
\end{tabular}

\section{HASIL DAN PEMBAHASAN}

Inkubasi secara in vitro ransum sapi perah selama 3 jam menghasilkan produk fermentasi mikroba rumen yang disajikan pada Tabel 2.

Tabel 2. Fermentabilitas ransum sapi perah berbasis jerami padi yang mengandung berbagai level konsentrat terfermentasi

\begin{tabular}{lccc}
\hline \multicolumn{1}{c}{ Peubah } & $\mathrm{R} 1$ & $\mathrm{R} 2$ & $\mathrm{R} 3$ \\
\hline Asam Lemak Terbang $(\mathrm{mM})$ & $163 \mathrm{c}$ & $126 \mathrm{~b}$ & $114 \mathrm{a}$ \\
$\mathrm{N}-\mathrm{NH}_{3}(\mathrm{mM})$ & $5,86 \mathrm{c}$ & $5,26 \mathrm{~b}$ & $4,27 \mathrm{a}$ \\
\hline
\end{tabular}

Keterangan : Superskrip yang berbeda kearah baris menunjukkan berbeda nyata $(P<0,05)$

Tabel tersebut menunjukkan bahwa rataan tertinggi asam lemak terbang dan $\mathrm{N}-\mathrm{NH}_{3}$ dicapai pada ransum sapi perah yang mengandung konsentrat tanpa fermentasi dan mengalami penurunan yang nyata $(\mathrm{P}<0,05)$ sejalan dengan meningkatnya penggunaan konsentrat terfermentasi dalam ransum. Namun secara umum masih dalam kisaran normal karena kadar asam lemak terbang dan $\mathrm{N}-\mathrm{NH} 3$ yang mendukung pertumbuhan mikroorganisme dalam rumen adalah 80-160 mM dan 4-14 mM, dan apabila nilai kurang dari kisaran tersebut maka proses fermentasi akan terganggu (Preston dan Leng 1987; McDonald et al. 2002).

Penurunan asam lemak terbang pada penggunaan konsentrat fermentasi disebabkan banyaknya karbohidrat terutama pati dan gula yang telah dimanfaatkan se- 
bagai sumber energi pada proses fermentasi, sehingga pasokan sumber karbohidrat bagi mikroba rumen untuk difermentasi menjadi asam lemak terbang menjadi berkurang yang berakibat pada produksi asam lemak terbang juga menjadi berkurang. Dengan demikian secara keseluruhan ransum sapi perah yang mengandung konsentrat terfermentasi memiliki konsentrasi asam lemak terbang yang rendah. Konsentrat yang digunakan memberikan porsi setengahnyan dari ransum sapi perah dibandingkan dengan jerami padi. Perubahan yang terjadi pada konsentrat akan berpengaruh besar pada keseluruhan ransum.

Dalam proses fermentasi membutuhkan energi agar proses tersebut berjalan dengan baik. Menurut Fardiaz (1992) mikroorganisme menggunakan karbohidrat sebagai sumber energi setelah terlebih dahulu dipecah menjadi glukosa. Pemecahan glukosa selanjutnya dilakukan melalui jalur glikolisis sampai akhirnya dihasilkan energi. Saccharomyces cerevisieae memiliki aktivitas dalam mencerna terutama sellulosa, pati, dan gula yang lebih (Suprayogi 2010). Dilaporkan oleh Umiyasih dan Anggraeny (2008) bahwa Saccharomyces cerevisiae yang diinkubasikan selama 72 jam pada ampas aren mempunyai serat kasar terendah. Sementara itu, EM-4 digunakan untuk mengoptimalkan pemanfaatan zat-zat makanan karena mikroorganisme yang terdapat dalam EM-4 dapat mencerna sellulosa, pati, gula (Surung, 2008). Menurut Sandi dan Saputra, (2012) bahwa penambahan EM-4 sebanyak 10\% (v/b) pada substrat mampu menurunkan kadar serat bahan.

Di sisi lain menurunnya kadar $\mathrm{N}$-amonia diduga terkait dengan jumlah asam lemak terbang yang dihasilkan lebih kecil pada perlakuan yang mengandung konsentrat terfermentasi dibandingkan dengan konsentrat tanpa fermentasi. Asam lemak terbang digunakan oleh mikroba untuk pertumbuhan bakteri termasuk juga bakteri proteolitik. Kekurangan asam lemak terbang akan mengurangi jumlah bakteri proteolitik dalam mencerna protein menjadi $\mathrm{N}-\mathrm{NH}_{3}$. Hal ini sesuai dengan pendapat Bryant dan Robinson, (1962) bahwa kebanyakan bakteri rumen memerlukan asam lemak terbang untuk pertumbuhannya.

Meskipun penggunaan konsentrat terfermentasi dalam ransum sapi perah berbasis jerami padi dapat menurunkan fermentabilitas dalam rumen secara in vitro, namun hasil menunjukkan masih dalam kisaran normal. Berdasarkan pengamatan secara organoleptik konsentrat terfermentasi memiliki aroma yang wangi dan lebih baik dibandingkan dengan konsentrat tanpa fermentasi, hal ini diduga akan disukai oleh ternak. Oleh karena itu pemanfaatannya sebanyak 50\% dalam ransum sapi perah tidak menjadi kendala yang berarti.

\section{KESIMPULAN}

Penggunaan konsentrat fermentasi dapat menurunkan fermentabilitas, namun masih dapat digunakan sampai 50\% dalam ransum sapi perah berbasis jerami padi.

\section{UCAPAN TERIMAKASIH}

Penelitian ini didanai melalui Program Penelitian Swadana Fakultas dengan SK Dekan Fakultas Peternakan No: 178/UN6.J/KP/2014. Oleh karena itu penulis mengucapkan banyak terimakasih kepada Dekan Fakultas Peternakan Universitas Padjadjaran yang telah memfasilitasi dan memberikan izin dalam melaksanakan kegiatan penelitian ini.

\section{DAFTAR PUSTAKA}

Bryant, M.P. and I. M. Robinson. 1962. Some nutritional requirements of predominant cultivable ruminal bacteria. J. Bacteriol. 84: 605- 614.

Callaway, E.S. and S.A. Martin. 1997. Effects of Saccharomyces cereviseae culture on ruminal bacterial that utilize lactate and digest cellulose. J. Dairy Sci. 20 : 2035-2044.

Conway, E. J. 1962. Ammonia. General method,. In microdiffusion analysis and volumetric error. Crosby Lockwood and Son Ltd., London. p. 98-100.

Eastridge M.L. (2006): Major advances in applied dairy cattle nutrition. J. Dairy Sci. 89: 1311-1323.

Fardiaz, S., 1992. Mikrobiologi Pangan I. Gramedia Pustaka Utama, Jakarta.

Markham, R. 1942. A steam distillation apparatus suitable for micro-Kjeldahl analysis. Biochem. J. 36: 790-791

McDonald P., R.A. Edward, J.F.D. Greenhagh, and C.A. Morgan. 2002. Animal Nutrition. Ed ke-6. Gosport: Ashford Colour Pr.

Preston T.R and R.A. Leng. 1987. Matching Ruminant Production System With Available Resources In The Tropics And Sub-Tropics. Penambul Books. Armidale

Reddy, N.R. and M.D. Pierson. 1994. Reduction in antinuttritional toxic components in plant foods by fermentation. Food Research International 27: 281-290.

Salcedo, G., L. Martinez-Suller, H. Arriaga, and P. Merino. 2010. Effects of forages supplements on milk production and chemical properties, in vivo digestibility, rumen fermentation and $\mathrm{N}$ excretionin dairy cows offered red clover silage and corn silage or dry ground corn. Irish Journal of Agricultural and Food Research 49:115-128.

Sandi, S., dan Saputra, A. 2012. The Effect of Effective Microorganisms-4 (EM4) Addition on the Physical Quality of Sugar Cane Shoots Silage. In International 
Seminar on Animal Industry.

Steel, R. G. D. dan J. H Torrie. 1993. Prinsip dan Prosedur Statistika. PT. Gramedia Pustaka Utama.

Suprayogi, W.P.S. 2010. Inkorporasi sulfur dalam protein onggok melalui teknologi Fermentasi menggunakan Saccharomyces cerevisiae. Caraka Tani XXV No.1, 34-38

Surung, M.Y. 2008. Pengaruh dosis EM-4 (effective microorganisms-4) dalam air minum terhadap berat badan ayam buras. Jurnal Agrisitem. Vol 4. No. 2,

Tilley, J. M. A. and R. A. Terry. 1963. A two stage technique for the in vitro digestion of forage crops. J. British. Grassl. Soc. 18: 104-111.

Umiyasih, U dan Y.N. Anggraeny. 2008. Pengaruh Fermentasi Saccharomyces cerevisiae terhadap Kandungan Nutrisi dan Kecernaan Ampas Pati Aren (Arenga pinnata MERR.). Seminar Nasional Teknologi Peternakan dan Veteriner 241-246.
Wanapat. 1985. Nutritional Aspects Of Ruminant Production In Southeast Asia With Special Reference in Thailand. Printed in Thailand by Funny Press, 549/1 Senanikom 1, Phaholyothin 32, Bangkok.

Wanapat, M., S. Kang, N. Hankla, and K.Phesatcha. 2013. Effect of rice straw treatment on feed intake, rumen fermentation, and milk production in lactating dairy cows. African Journal of Agricultural Research. Vol. 8 (17) $1677-1687$.

Wardhani, N.K. dan A. Musofie. 1985. Respon Sapi Perah Dara terhadap Pemberian Wafer Pucuk Tebu dan Rumput Gajah. Proc. Seminar Pemanfaatan Limbah Tebu untuk Pakan Ternak. Pusat Penelitian dan Pengembangan Peternakan, Bogor. hal. 56-6o.

Westby, A., A. Reilly and Z. Bainbridge. 1997. Review of the effects of fermentation on naturally occurring toxins. Food Control. Vol. 8 No. 5/6 329-339. 